\title{
Publisher Correction: Clinical Features of Neuroblastoma With 11q Deletion: An Increase in Relapse Probabilities In Localized And 4S Stages
}

\author{
Antonio Juan Ribelles, Sandra Barberá, Yania Yáñez, Pablo Gargallo, Vanessa Segura, \\ Bárbara Juan, Rosa Noguera, Marta Piqueras, Victoria Fornés-Ferrer, Jaime Font de Mora, \\ Adela Cañete \& Victoria Castel
}

Correction to: Scientific Reports https://doi.org/10.1038/s41598-019-50327-5, published online 24 September 2019

The original version of this Article contained a typographical error in the spelling of the author Antonio Juan Ribelles, which was incorrectly given as Antonio J Ribelles.

As a result, the Author Contributions statement,

"Antonio J Ribelles and Adela Cañete: Main authors. Wrote manuscript text. Sandra Barberá and Bárbara Juan: Data collection and english translation. Yania Yáñez, Pablo Gargallo and Victoria Castel: Wrote parts of the manuscript. Vanessa Segura, Rosa Noguera, Marta Piqueras and Jaime Font de Mora: Molecular testing. Sample management. Victoria Fornés-Ferrer: Biostatistical analysis."

now reads:

“Antonio Juan Ribelles and Adela Cañete: Main authors. Wrote manuscript text. Sandra Barberá and Bárbara Juan: Data collection and english translation. Yania Yáñez, Pablo Gargallo and Victoria Castel: Wrote parts of the manuscript. Vanessa Segura, Rosa Noguera, Marta Piqueras and Jaime Font de Mora: Molecular testing. Sample management. Victoria Fornés-Ferrer: Biostatistical analysis."

These errors have now been corrected in the PDF and HTML versions of the Article.

(1) Open Access This article is licensed under a Creative Commons Attribution 4.0 International License, which permits use, sharing, adaptation, distribution and reproduction in any medium or format, as long as you give appropriate credit to the original author(s) and the source, provide a link to the Creative Commons license, and indicate if changes were made. The images or other third party material in this article are included in the article's Creative Commons license, unless indicated otherwise in a credit line to the material. If material is not included in the article's Creative Commons license and your intended use is not permitted by statutory regulation or exceeds the permitted use, you will need to obtain permission directly from the copyright holder. To view a copy of this license, visit http://creativecommons.org/licenses/by/4.0/.

(c) The Author(s) 2020 